dr. Ana Krajnc

Filozofska

fakulteta $v$

Ljubljani

\title{
KDO ODLOČA O TEM, ČESA SE BODO LJUDJE UCLLLI?
}

\section{Programiranje v izobraževanju odraslih}

I

zobraževanje odraslih vsebinsko izhaja iz ljudi, njhovih potreb, problemov in interesov. Kljub temu ni toliko razdrobljeno, da ne bi imelo skupnih ciljev, na osnovi katerih se $\mathrm{v}$ posamezni družbi vodi prosvetna politika ali politika izobraževanja odraslih. Posamezni programi se sestavljajo kratkoročno, prilagojeno ljudem. Glede na prednosti, ki jih družba določa v svojih ekonomskih in socialnih ciljih, pa so določena področja izobraževanja odraslih vnaprej dolgoročno izbrana, na primer odpravljanje funkcionalne nepismenosti, povečanje in decentralizacija izobraževalne ponudbe, izobraževanje za premagovanje zaposlitvene ogroženosti starejših delavcev, dopolnilno izobraževanje učiteljev, strokovno izobraževanje $\mathrm{v}$ ustanovah in podjetjih itd. (Nacionalni program izobraževanja odraslih, I. del, 1998). Lep primer povezovanja individualnega in družbenega programiranja izobraževanja odraslih je projekt ministrstva za delo in zavodov za zaposlovanje Pet tisoč mladih brezposelnih. Projekt je potekal kot širše družbena izobraževalna mreža, obenem pa so mentorji na podlagi andragoškega svetovanja pomagali pripraviti vsakemu od kandidatov njemu primeren izobraževalni program (Nacionalni program izobraževanja odraslih, II. del, 1999).

Nacionalni program izobraževanja odraslih predvidi prednostna področja, izbere ciljne skupine (na primer invalidi, ženske, ljudje v manjših krajih, mladi brezposelni od 16. do 25. leta starosti itd.). Nastaja na podlagi dr- žavnih načrtov za razvoj in iz spoznanj raziskav o vzgojni stvarnosti. Podobno kot v indidvidualnih programih se tudi nastajanje nacionalnega programa za izobraževanje odraslih praviloma giblje med dvema determinantama: cilji, ki jih želi doseči družba (politika), in stanjem v praksi, od koder bodo začeli izobraževalci, upoštevaje, kaj je že uresničeno in kaj še ni. Nacionalni program naj bi ustrezal obema. Vrednost programiranja je odvisna od predhodnega raziskovanja, poznavanja podatkov o stanju v praksi in odkrivanja, kakšne so razvojne težnje, usmeritve (Field, Schuller, 1999).

Tudi pri sestavljanju individualnih izobraževalnih programov ali programov za posame-

Kdo sme odločati o tem, česa naj se ludje učijo, in $v$ imenu česa odločajo, je pomembno filozofsko vprašanje. Vleče se skozi vso zgodovino pedagogike. O tem so pisali Komensky, Rousseau, Pestalozzi, Kant, Dewey in drugi. Nihovi pogledi se med seboj razlikujejo. Komensky in Kant poudarjata pomen vzgoje pri prenašanju tradicije in kulture. Rousseau poudarja, naj vzgoja ne utesnjuje otroka, ampak naj bo toliko svobodna, da omogoči razcvet njegove narave, ki je vzgojitelji ne smejo zatreti. Ameriški avtor Dewey, ki piše o izobraževanju v industrijskem obdobju, je bolj pragmatičen. Cilje vzgoje in s tem tudi vsebine izobraževanja podredi vsakdanjim potrebam industrijskega dela in življenja. 
zno učno skupino je raziskovanje zelo pomembno. Izobraževalci kot analitiki in raziskovalci ugotavljajo, kakšno je začetno stanje, koliko ljudje že znajo in kaj se morajo še naučiti. Nastajajoči izobraževalni programi se gibljejo med cilji in realnostjo.

Vsi pa imajo v mislih otroke, ko razpravljajo o vzgojnih ciljih in vsebinah. O vzgoji in izobraževanju odraslih govori le Komensky, in sicer v knjigi Pampaedia, delo, ki ni bilo znano do nedavnega, saj je ideja Komenskega o vseživljenjskem izobraževanju preveč prehitevala razvoj (Vidmar, 1995).

Vlado Schmidt svojo vzgojno teorijo opira na dialektični materializem in poudarja, da vzgojne cilje in programe vedno določa »vladajoči razred«. Danes bi rekli, da odloča stranka, ki je na oblasti, o tem, česa se bodo ljudje učili in kakšni bodo izobraževalni programi. Za tem stoji vladajoča ideologija (Schmidt, 1982)

Šolski sistem deluje po natančno predpisanih učnih načrtih, v izobraževanju odraslih se vsebine (programi) sestavljajo sproti in izhajajo iz ljudi, ki se izobražujejo. Izobraževalci imajo v izobraževanju odraslih precej drugačen položaj, kot ga ima učitelj v šoli. Temeljna naloga učitelja je še vedno upoštevati učni načrt in podajati učno snov. Osrednja strokovna naloga andragogov je odkrivati potrebe po znanju, animirati ljudi za izobraževanje, pripravljati izobraževalne programe in predvideti tudi njihovo oblikovno izvedbo (trajanje, zgoščenost izobraževanja, učne enote, vire in način izobraževanja). Svetuje, vodi, krmili izobraževanje. Le redko učno snov tudi podaja. Pomembno vlogo ima tudi pri programiranju. Izobraževanje potem poteka po osebnih poteh in se v osebnih situacijah individualizira.

Povpraševanje po znanju je pri odraslih zelo raznoliko, zato ga je težko ali skoraj nemogoče vnaprej predvideti. Izobraževanje odraslih je zelo odvisno od sprotnega programiranja.
To mu daje nove družbene vloge, kot so inovativnost, razvojna vloga, prilagoditvena vloga in v »zašolani« družbi komplementarnost in prožnost znanja. Ker država ne more imeti tolikšnega nadzora nad izobraževanjem odraslih, kot ga ima nad šolskim sistemom, je do njega bolj mačehovska in ga $\mathrm{v}$ primerjavi $\mathrm{s}$ šolo zapostavlja (Nuiss1, 1998).

Seveda vloge države pri po-

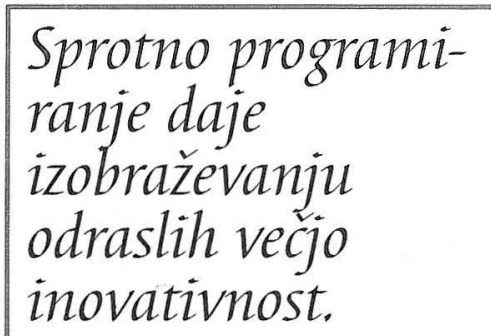
stavljanju vzgojnih ciljev in določanju izobraževalnih programov ni mogoče obravnavati poenostavljeno. Res se pri tem zanemarja individualnost, toda vsak človek mora živeti v določeni družbi in ta ima svoje lastnosti. Vzgoja je družbeni proces. Človek se vzgaja za določeno družbo, za resnični svet, in se ne more socializirati brez nje. Vzgoje brez družbe ni. Tako kot je prevelik ideološki pritisk družbe na vzgojo lahko škodljiv in zavira vzgojo posameznika, tako je družbeni okvir tudi pogoj, da vzgoja sploh obstaja. Optimalne rezultate bi dala vzgoja, $v$ kateri sta individualno in družbeno uravnovešena (Ziegler, 1997).

Vzgoja, ki jo določajo družbeni cilji, uradna ideologija in vladajoča politika, se ne posveča posameznikovim potrebam. Vzgojne cilje in izobraževalne programe izpeljuje iz posplošenih družbenopolitičnih potreb. Pri tem se zanemarjajo individualnost, osebne potrebe in posebnosti posameznika ter njegovega intimnega sveta, ki so lahko najmočnejšsa vzgojna sestavina.

Kdor določa človeku, česa se naj se nauči, odloča o njegovem življenju in o njegovih najosebnejših zadevah. To, da drugi predpisujejo, kaj naj se človek nauči, se zdi še absurdnejše v izobraževanju odraslih, ko so ljudje samostojni in sami odločajo o vsem, kar počnejo, le o svojem izobraževanju ne bi smeli. Toda tudi znanje, ki ga pridobivajo, ne bodo uporabili v nekem »brezzračnem prostoru«, ampak v dejanskih, resničnih družbenih raz- 
merah. Zato imajo vzgojni cilji odraslih kljub močno poudarjenemu individualnemu pristopu tudi primesi družbenega. Občutek za družbeno skupnost, razmere $\mathrm{v}$ državi in težnje družbenega razvoja bi moral imeti, jih poznati in upoštevati vsakdo, ki izbira izobraževalne vsebine in sestavlja izobraževalne programe, za sebe ali za druge. Če izobraževalni program ne upošteva posameznika, če ne nastaja na osnovi njegovih lastnosti in posebnosti, učenje ni uspešno, ker ni povezano $\mathrm{z}$ učencem.

Če izobraževalni
program ni
povezan z
učencem, učenje
ni uspešno.

Kdaj si torej ljudje lahko sami postavljajo izobraževalne cilje in kdaj so (tudi odrasli) odvisni od tega, da jim cilje in program pripravijo drugi?

Posameznik, ki je šele na začetku svojega razvoja (na primer funkcionalno nepismene osebe, $\mathrm{z}$ manjšo formalno izobrazbo, ozkimi interesi in nerazvitimi sposobnostmi ter slabo poučene) nedvomno $\mathrm{v}$ svojem razvoju ne bi prišel daleč, čeprav je odrasel, če bi si sam postavljal vzgojne cilje in sam izbiral vsebine svojega izobraževanja. Pri tem gotovo potrebuje zunanjo pomoč, pomoč druge osebe: mentorja, svetovalca za izobraževanje - andragoga. Sam se svojih potreb ne zaveda dovolj jasno. Sočasno je od izobraževanja toliko odmaknjen, ker mu prej v življenju ni šlo dobro, da ne bi iskal rešitev za svoje probleme prav v izobraževanju, čeprav bi bila morda to edina možna pot do uspeha (Krajnc, 1994).

Danes se ljudje pogosto znajdejo v položaju, ko jim zmanjkuje znanja. To hitro opazijo, če ne morejo nečesa opraviti, doseči, preseči, napraviti. Življenjske okoliščine porajajo $\mathrm{v}$ njih željo, da bi se tega, kar ne znajo, naučili. Pred očmi imajo zlasti cilj, ki bi ga z novim znanjem radi dosegli. Ostaja vprašanje, česa bi se zares morali naučiti, katere teme, katere vsebine. Programiranje je ena od faz andra- goškega ciklusa (druga po vrsti), je postopek izbire in povezovanja izobraževalnih vsebin.

\section{NA OSNOVI ČESA IZBIRAMO TEME IN SESTAVLJAMO IZOBRAŽEVALNI PROGRAM?}

Izbira vsebin narekuje cilj, ki ga ima nekdo pred seboj. Določa pa ga tudi stanje osebe, učenca. Nekateri imajo do cilja daljšo pot in se morajo še marsičesa naučiti »za nazaj«, drugi so na primer bliže cilju, če so si del potrebnega znanja že prej sami pridobili po raznih osebnih poteh in izrabili izobraževalne možnosti v okolju. Pri prvih bodo andragogi programu dodali tudi take teme, ki jih na začetku niso nameravali ali za katere se zdi, da s samim ciljem niso povezane. Drugim bodo program skrčili na tiste teme, ki jih zares še ne obvladajo. Vzemimo na primer nekoga, ki je prišel na tečaj angleščine, zelo slabo pa pozna tudi slovensko slovnico. Programiranje angleškega tečaja se $\mathrm{v}$ takih primerih ne bo moglo osredotočiti samo na angleščino. Dopolniti bo treba tudi znanje slovenske slovnice. Lahko pa vzamemo drug primer: delavci v gradbeništvu si želijo pridobiti srednješolsko izobrazbo gradbenega tehnika. Glede na njihove večletne izkušnje $v$ gradbeništvu bodo programerji v programu, predvidenem za redne šole, izpustili nekatere vsebine, na primer gradbeni materiali (o tem morda vedo več in imajo novejša znanja kot učitelji), organizacija dela na gradbiščih itd. Ali pa: program seminarja za koncipiranje, organizacijo in postavljanje razstav bodo izobraževalci drugače zastavili, če so udeleženci že nekaj časa v službi v galerijah ali če so novinci na tem področju.

Vzgojno-izobraževalni cilji in udeleženci sta dve glavni determinanti programiranja $v$ izobraževanju odraslih. To izobraževalcem določa, kje bodo začeli in do kod morajo priti na koncu izobraževanja. 


\section{NAPAČNA IZBIRA VSEBIN} ZAVLAČUJE UČENJE

»Zadeti« prave vsebine je danes ena najtežjih nalog izobraževanja. Z razvojem se je nakopičilo zelo veliko novega znanja. Kroženje znanja se globalizira, z novo tehnologijo (internet, elektronska pošta, cd-romi) in tudi prek klasičnih virov so na voljo brezmejne količine znanja. Ker je ponudba velika, je mnogo teže izbirati kot prej, ko je bilo znano, da je samo en priročnik ustrezen, da je samo ta in ta avtor zanesljiv ter ima ustrezne podatke itd. Izbira in racionalno ravnanje, ko izobraževalec ali oseba, ki se uči, sama skuša zaokrožiti vsebine izobraževanja, sta potrebna, ker se čas med odkritjem, da nekaj ne vemo, in časom, ko bi morali to že vedeti, vztrajno krajša. Čim hitrejši je ritem življenja, tem krajši je čas med neznanjem (spoznanjem, da se moramo nekaj naučiti) in znanjem (trenutkom, ko bi to morali znati). Ljudje izgubljajo veliko časa in si zelo prizadevajo, ne da bi se naučili, kar potrebujejo, če so pri programiranju ubrali različne stranpoti in se pri izbiri učne snovi napačno odločali. Ljudje se v takih primerih učijo nekaj, kar jim v tistem času ni ravno najbolj potrebno. Ko spoznajo, da po tej poti ne bodo prišli do cilja, poiščejo druge vsebine, program popravljajo, spreminjajo in se začno učiti nekaj drugega. Če se napačne odločitve pri programiranju večkrat ponovijo, lahko preteče veliko časa in ga zmanjka za to, da bi še pravočasno dosegli pravi cilj, razpolagali s potrebnim znanjem. Znanje je danes gonilna sila preživetja. Drucker govori o »družbi znanja«. Ljudje, ki si sproti ne pridobivajo potrebnih znanj, zaidejo v težave in so lahko celo eksistenčno ogroženi. Zato je odgovornost pri programiranju izobraževanja danes še toliko večja, kot je bila nekoč, ko so tudi ljudje brez znanja lahko preživeli z delom svojih rok. Naglica v načinu dela in življenja narekuje tudi naglico v izobraževanju. Tudi tu se je treba hitro in pravilno odločati. Izbiranje vsebin izobraževanja je strnjen proces odločanja: odločanje o tem, kaj naj vključimo v program in kaj glede na vzgojni cilj ter učence, ni primerno oziroma ni potrebno.

\section{TIMSKO PROGRAMIRANJE IZOBRAŽEVANIA ODRASLIH}

Potrebe po izobraževanju odraslih nastajajo iz konkretnih, praktičnih razlogov. Ljudje se želijo nekaj naučiti, ker nameravajo potovati $\mathrm{v}$ tujino, ker bi radi zamenjali delo, ker je otrok zbolel za kronično boleznijo, ker so se jim zmanjšali družinski dohodki in bi radi delali določene stvari sami, ker bi radi raziskovali, ker čutijo potrebo po izražanju v umetnosti, ker bi radi drugače opremili stanovanje, ker bi radi vozili avto itd. Potreb po znanju je nešteto in jih je težko predvideti. Pogosto si ljudje z izobraževanjem in novim znanjem želijo rešiti določen problem. Problemi pa niso nikoli monodisciplinarni. Zato je programiranje izobraževanja interdisciplinarno. Problema ni mogoče rešiti samo z znanjem psihologije, ekonomije

Andragogika spod-
buja problemsko
oziroma interdi-
sciplinarno
programiranje
izobraževanja.
ali katerekoli druge vede. Rešitve zahtevajo vsestransko znanje, spretnosti, nove navade in kombinacijo informacij iz različnih strok. Tako govorimo $\mathrm{v}$ andragogiki o problemskem programiranju izobraževanja, izhajamo iz problemov (potreb deficita ali suficita), in ne iz posamezne znanstvene discipline. V program vključimo vse, kar bo učencu pomagalo priti do cilja, rešiti problem, opravljati drugačno delo ali se drugače počutiti in izražati kot prej.

Problemsko programiranje izobraževanja odraslih zahteva timsko delo. Pri programiranju sodelujejo na primer zdravnik, pravnik, 
psiholog, upravnik določene ustanove, ekonomist in andragog. Drug tim lahko sestavljajo biolog, arhitekt za urejanje krajine, predsednik ribiškega društva, inženir za reciklažo odpadkov. Priložnostnih skupin, ki sodelujejo pri sestavljanju programov, je lahko veliko. Andragog mora imeti jasno predstavo, kaj od posameznega strokovnjaka potrebuje, in mu mora pri sestavljanju izobraževalnega programa dodeliti jasno vlogo. Timi se od enega izobraževalnega programa do drugega spreminjajo. Andragog jih sestavlja ad hoc, lahko samo za eno učno skupino ali celo sestavi izobraževalni program za posamezno osebo (Merrill, 1997).

Andragog pri programiranju nastopa $v$ vlogi koordinatorja in skrbi za čim boljšo didaktično povezanost in enotnost programa. $S$ tem da izobraževalnemu programu celovito podobo, podrejeno izobraževalnemu cilju in prilagojeno učencem ter možnostim okolja. Presodi, kako izobraževalni program ustreza potrebam ljudi.
$\mathrm{Na}$ vsakega od strokovnjakov se andragog obrača po potrebi, glede na to, kako se pojavljajo posamezni problemi v postopku programiranja. Ljudje so prezaposleni z lastnim delom in pri izobraževanju sodelujejo, če se to sodelovanje prilagaja njihovim možnostim. Zato ni nujno, da bi se v postopku programiranja sestajal ves tim, andragog se lahko zaporedoma sestane s posameznimi strokovnjaki in se $\mathrm{z}$ vsakim podrobno pogovarja, tako da skupaj pretehtata, kaj bi iz njegove stroke vključili v program. Andragog je edini, ki ima celovit pogled na program in pregled nad znanji, ki so jih za program predlagali posamezni člani tima. Čeprav se zdi programiranje v izobraževanju odraslih zelo kompleksen in zahteven postopek, je po drugi strani preprosto povezan s tem, česa bi se ljudje želeli naučiti. Tim strokovnjakov naj ne bi nikoli izpustil izpred oči ljudi in strpal $\mathrm{v}$ program vse, kar se jim zdi v lastni znanstveni disciplini pomembno, čeprav bi lahko ljudje svoje cilje dosegli tudi brez takih znanj.

\section{PROGRAMIRANJE V POVEZAVI S STROKOVNJAKOM}

Če je potreba po znanju začrtana ožje, se andragog posvetuje le $\mathrm{z}$ enim strokovnjakom in vsaj v začetni fazi ni potreben ves tim. Predstavi mu vzgojno-izobraževalni cilj, česa se želijo ljudje naučiti in kaj že znajo, in nato skupaj izbirata ustrezne teme (Usher, Edwards, 1994).

Andragog ni polihistor, ki bi se spoznal na vse vede in področja znanja. Skoraj ni mogoče, da bi se pri programiranju, izbiri in strukturiranju izobraževalnih vsebin zanašal samo na svoje znanje, ker je povpraševanje ljudi po znanju zelo raznoliko in razpršeno. Ljudje iščejo znanja, ki jih je vnaprej težko predvidevati, potrebe se porajajo sproti, stvarnost se naglo spreminja in $\mathrm{s}$ tem tudi nova znanja. Andragog kot strokovnjak obvlada strategijo programiranja v izobraževanju odraslih, konkretne vsebine predstavijo strokovnjaki za posamezno vedo. Zato je v tem primeru programiranje timsko. Sodelovanje med andragogom in strokovnjakom za druge vede je pomembno tudi zato, ker andragog pozna učno skupino in posamezne osebe s potrebami po tem znanju. V dialogu med obema se pokažeta obe determinanti programov in šele takrat nastane prilagojen program $\mathrm{z}$ upoštevanjem učne skupine ter stroke, vede oziroma vzgojno-izobraževalnih ciljev.

Kdor sestavlja program, mora o temi (učni snovi) veliko vedeti. Zato se izobraževalci povežejo $s$ strokovnjaki $s$ posameznega področja in $\mathrm{z}$ njihovo pomočjo dobijo izobraževalci, andragogi jasen pregled nad vsebino. Razpoznati je treba najpomembnejše teme, v programu ne sme manjkati nobena, če gre za temeljna znanja.

Lahko pa opazujejo neposredno prakso in na 
osnovi empiričnih ugotovitev odkrivajo, kaj je treba vključiti v izobraževalni program. Če na primer usposabljamo farmacevte za lekarniško svetovanje in informiranje strank, bomo opazovali neposredno prakso v lekarnah. Programerja bo zanimalo, kakšni pogovori potekajo v lekarnah, kaj stranke sprašujejo, katere informacije o zdravilih in načinu jemanja zdravil so za paciente pomembne, kakšne napake in nevarnosti bi svetovanje farmacevta lahko preprečilo, kakšen jezik (pojmi, diskurzni nameni, jezikovne funkcije in katera govorna dejanja) ljudje obvladajo itd. (Diemer, Peters, 1998).

Strokovnjak, s katerim se posvetuje andragog in pri programiranju $\mathrm{z}$ njim sodeluje, naj praviloma ne bi bil univerzitetni profesor ali znanstvenik, ker se bo kot tak težko vživel v praktične potrebe ljudi. Kako naj na primer pripravi univerzitetni profesor učni načrt za določen predmet $\mathrm{v}$ četrtem razredu osnovne šole in pri tem nima nobenih drugih izkušenj $\mathrm{z}$ učenjem otrok, razen spominov na svoj četrti razred, ko je bil še otrok. Imeti bi moral sposobnost vživljanja v učenca in empatije, občutek za podrobnosti v življenju in o tem, kakšne reakcije lahko pri učencih nastanejo. Strokovnjak, ki sodeluje z andragogom, mora biti tudi praktik z bogatimi osebnimi izkušnjami in možnostjo predvidevanja, kako bi tak ali drugačen program učinkoval (Ziegler, 1997).

\section{KADAR IZOBRAŽEVANJE PROGRAMIRA ANDRAGOG}

Če andragog ne more $v$ svojem okolju najti ustreznega strokovnjaka, se sam poglobi $\mathrm{v}$ snov, študira po različnih virih in avtorjih ter tako postopoma sestavlja program. Pri svojem delu se kar pogosto znajde v taki situaciji (Vogel, 1998). Znanja, ki jih iščejo odrasli, niso vedno jasno povezana $\mathrm{z}$ določenim strokovnim področjem oziroma problem ni nepo- sredno povezan z določeno znanstveno disciplino, zato ni strokovnjakov. Program je treba sestaviti povsem na novo, upoštevaje različne knjižne in druge vire. Nazoren primer tega je bila potreba organizacije Amnesty International $\mathrm{v}$ zvezi $\mathrm{z}$ vsestranskim razumevanjem vprašanja smrtne kazni. Izobraževalnih programov v zvezi s tem ni bilo, tako da so jih morali andragogi pripraviti sami. Pomemben vir za to, česa bi se morali ljudje naučiti, so tudi ljudje, ki so kaj podobnega že sami počeli (Taylor, Tremblay, 1997).

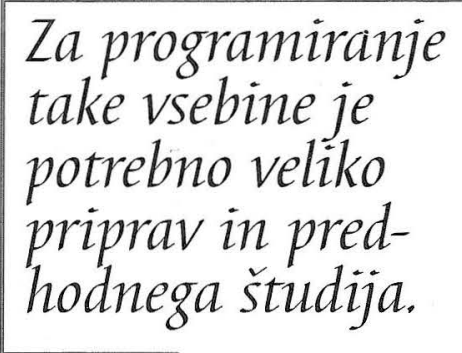

Andragog programira izobraževanje le $\mathrm{v}$ nekaterih primerih:

- kadar ni posebnih strokovnjakov za to, kar bi se radi ljudje (še) naučili (na primer nove specializacije v stroki);

- kadar imajo odrasli premalo izobrazbe in so osebnostno premalo razviti, da bi lahko sami programirali svoje izobraževanje (na primer funkcionalno nepismeni ljudje);

- kadar je treba sestaviti program za širše teme, ki jih ni mogoče neposredno povezati z določeno znanostjo ali stroko (na primer ekološko osveščanje, informiranje prebivalstva o novih prometnih predpisih);

- kadar je program namenjen množičnim oblikam izobraževanja in subjekta izobraževanja ni možno natančneje določiti; tako izobraževanje je namenjeno vsakomur, ki ga želi uporabiti, in spada v splošno izobraževalno ponudbo javnosti (na primer radijski izobraževalni program, televizijske izobraževalne oddaje, objave izobraževalnih besedil v dnevnem tisku).

Pri pripravi takih programov andragog uporablja raziskovalno-analitični pristop. Izbira različne razpoložljive vire, študira in izloči najpomembnejše teme. »Spušča《 se tudi v podrobnosti. Sestavlja program, ki je upora- 


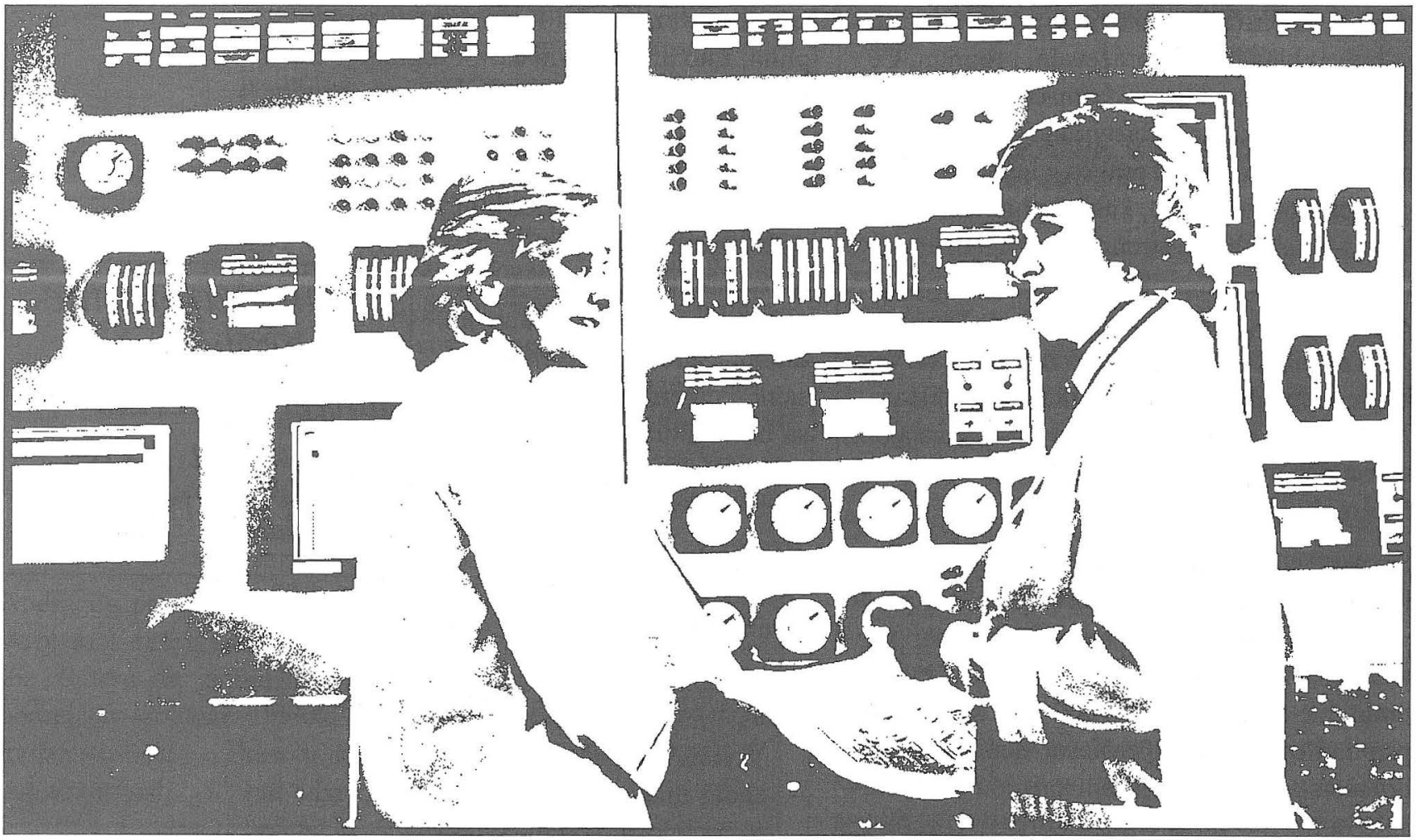

ben in primeren za različne ljudi. Če se andragog loti izobraževalne teme povsem na novo, ima pred seboj veliko priprav in predhodnega študija ter raziskovanja, preden se loti sestavljanja programa. Če mora večkrat programirati vsebine $\mathrm{z}$ istega področja, se postopoma $\mathrm{v}$ njem udomači in postane zanj kompetenten. $S$ prakso $\mathrm{v}$ izobraževalni dejavnosti postane kompetenten za programiranje tudi na več področjih znanja, kot so usposabljanje za družinske vloge, obnavljanje in razvijanje rekreativnih ter športnih navad pri ljudeh v srednjih letih, usposabljanje ljudi za kakovostnejše medosebne odnose, izobraževanje diabetikov ali drugih pacientov s kronično boleznijo, usposabljanje gorskih vodnikov, računalniško, predupokojitveno izobraževanje, izobraževanje za prosti čas itd. (Vogel, 1998).

Primeri, ko mora izobraževanje programirati andragog, so zelo različni. Pri nekaterih je učna skupina znana, pri drugih ni. Včasih to nalogo opravlja andragog zaradi pomanjkanja strokovnjakov, včasih pa je izobraževanje množično in narekuje potrebe po programih. Ali pa programira program sam, na primer pri funkcionalno nepismenih, ker jih $\mathrm{v}$ izobraževanje vodi prek osebnih stikov s posamezniki. Vsakokrat uporabi drugačne strategije programiranja, od tega, da se posveti skrajni individualizaciji programov, do tega, da da $v$ javnost posplošen program. Kdaj sam prevzame odgovornost za programiranje izobraževanja, je odvisno od njegovih osebnih nagnjenj: ali se nagiba bolj k andragoškemu svetovalnemu delu in vodenju posameznikove izobraževalne poti ali raje pripravlja širše programe za javnost.

Pomembne odgovornosti prevzema andragog tudi kot koordinator pri timskem in tandemskem programiranju skupaj z drugim strokovnjakom, ki je morda pozneje tudi izvajalec izobraževanja. 


\section{KADAR IZOBRAŽEVANJE PROGRAMIRA POSAMEZNIK SAM}

Alen Tough, profesor na inštitutu za izobraževanje odraslih na univerzi v Torontu, se je s svojim raziskovalnim timom nekaj desetletij posvečal raziskovanju učnih projektov odraslih. Pozornost je posvetil predvsem izobraževanju »v lastni režiji«, kadar si ljudje sami urejajo izobraževanje po osebni poti. To pride v poštev zlasti pri neformalnih oblikah izobraževanja odraslih. Ugotavlja, da je razmerje med formalnim ter neformalnim izobraževanjem odraslih $20: 80$ in dokazuje vse večji pomen slednjega pri vseživljenjskem izobraževanju (Tough, 1972, str. 72-97). Učni projekti odraslih so tipična oblika izobraževanja, ko programira izobraževanje posameznik sam. Ko sam ugotovi potrebo po znanju, si postavi jasnejši cilj, kaj bi se moral naučiti, in sestavlja vsebine. Poleg tega, da je sposoben sam ugotoviti potrebo in se nato posvetiti programiranju, opravi pri učnih projektih tudi druge faze andragoškega ciklusa: načrtuje, se samostojno uči in tudi ocenjuje uspešnost svojega učenja. Po študijah, opravljenih v Kanadi, naj bi imel vsak povprečno razvit odrasli do 15 pomembnejših učnih projektov na leto.

Toliko samostojnosti pri izobraževanju zmorejo ljudje iz socialno in kulturno razvitega okolja ter z najmanj štiriletno srednješolsko izobrazbo. To je tudi meja funkcionalne pismenosti (Krajnc, 1994). Pri drugih namreč ne moremo pričakovati, da bodo sami programirali svoje izobraževanje.

Človek laže zastavi svoje izobraževanje, če se ne loti snovi čisto na novo, če je tema sorodna njegovi stroki, poklicu, delu, če se je $\mathrm{z}$ njo srečal že kdaj prej ali če lahko o tem sliši tudi doma. S tem je tudi manjša verjetnost, da bo pri izbiri vsebin delal napake.

Če nekdo sam programira svoje izobraževanje, še ne pomeni, da se ne bo tudi posvetoval z drugimi (prijatelji, sorodniki, sosedi, sodelavci, strokovnjaki ali andragoško svetovalno službo) in se šele nato odločil, kaj se bo zares učil. Posvetovanje razširi njegove poglede in merila, odločitev pa je še vedno njegova domena.

Pogosto je sestavljanje vsebin lastnega izobraževanja tako zahtevno, da potrebuje oseba strokovno pomoč. Andragoško svetovalno delo se vse bolj širi. Ljudem posreduje podatke o tem, o čem in kako naj bi se izobraževali. Nasveti so odprti, koliko jih upoštevajo, je stvar osebne odločitve. Svetovalec se vživi $\mathrm{v}$ osebo, njene možnosti, znanje in neznanje in izbira vsebine. Svetovalec od zunaj natančneje opazi ter objektivneje Ljudje iz socialno in kulturno bogatega okolja so bolj pripravljeni programirati lastno izobraževanje. oceni, katerim temam bi bilo treba pri izobraževanju dati prednost in katere opustiti (Rees, Barlett, 1999).

\section{NAČRTOVANJE OSEBNE IZOBRAŽEVALNE POTI IN PROGRAMIRANJE IZOBRAŽEVANJA ODRASLIH}

Pri splošnem pomanjkanju znanja in zahtevah informacijske družbe, da se ljudje vse življenje izobražujejo, postanejo enkratni, neponovljivi in imajo izvirne zamisli, posamezne izobraževalne faze, ta ali oni program, več ne zadostujejo. Vsaka oblika izobraževanja naj bi bila osmišljena in povezana z življenjskim izobraževalnim načrtom. Ker je hitrost pridobivanja znanja vse pomembnejša, veliko pripomore sistematični pristop $\mathrm{k}$ izobraževanju. Nov izobraževalni program bo uspešnejši, če ni osamelec, če je smiselno povezan s posameznikovimi predhodnimi učnimi prizadevanji.

Povezave med posameznimi oblikami izobraževanja povečujejo človekovo samostojnost $\mathrm{v}$ izobraževanju. Če je izobraževalna tema kakorkoli povezana s prejšnjimi, se pri učenju hitro znajde in se laže sam odloča. 
Vsak program izobraževanja odraslih naj bi imel poleg kratkoročnih ciljev (na primer znati obrezovati sadno drevje, pridobiti si sposobnosti za vodenje, povečati svoje sposobnosti za vživljanje v druge, naučiti se računalniškega jezika itd.) tudi dolgoročne (priti na vodilno mesto, delati to, kar nekoga veseli, povečati dohodke, izboljšati odnose $z$ drugimi, samozaposlitev itd.). Izobraževalni program postane osmišljen, če je izdelan tudi izobraževalni načrt kot podlaga življenjske kariere. To zahteva prav določen program, zato se posameznik ne odloči za katerokoli izobraževanje.
Povezave med izobraževalnimi programi za likovno oblikovanje lepakov, oblikovanje keramike, organizacijo razstav, japonsko tehniko glaziranja keramike nastajajo v okviru začrtane življenjske kariere (na primer človek želi postati znan in uspešen umetnik). Izobraževalni programi za bodočega kulturnega managerja, industrijskega oblikovalca ali nekoga, ki ga kultura zanima le kot del splošne izobrazbe, bodo drugače sestavljeni in $\mathrm{v}$ drugačnem zaporedju. Težko si je zamisliti, da pri programiranju in načrtovanju življenjske kariere ter izobraževalnem načrtu ne bi imel glavne besede učeči se posameznik. Mentor in svetovalec sodelujeta bolj pri posameznih programih, ko je treba izobraževalne vsebine natančneje izbirati (Rees, Barlett, 1999).

Pogosto slišimo o krizi identitete, pojavlja se zlasti pri mladih ljudeh. Na vprašanje »Kdo sem in kaj sem, kaj nameravam v svojem življenju, kaj so moji cilji?« si marsikdo ne zna

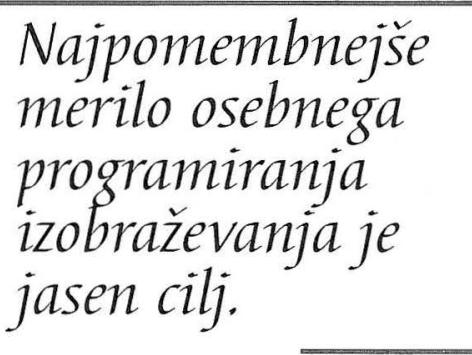
jasno odgovoriti. Zato tudi nima meril za izbiranje izobraževalnih vsebin. V izobraževanje se vključuje bolj po naključju ali po zunanjih trivialnih merilih, kot so: kateri seminar manj stane, katero izobraževanje je bliže domu, kam so se vpisali prijatelji, po tem, kateri oglas za programe je napravil nanj največji vtis, itd. V izobraževanje se človek brez jasne osebne identifikacije ne vključuje načrt- no, glede na vnaprej postavljen življenjski cilj, ampak bolj pod vplivom okolja in razmer.

Človek, ki ve, kaj hoče v svojem življenju, se tudi izobražuje zelo strukturirano in po strogo izbranih izobraževalnih programih. Vsako učenje ima pri njem svoj namen. Tako skrajša pot do izobraževalnih in osebnih ciljev (Billet, 1998).

Šolanje v otroštvu in študij v mladosti sta pomemben del osebnega izobraževalnega načrta. Mladi odkrivajo, da jim en študijski program na fakulteti ne zadošča več pri uresničevanju življenjske kariere. Tudi pri nas so čedalje pogostejši primeri vzporednega študija. Glede na osebni izobraževalni načrt študentje kombinirajo več študijev, na primer diplomirajo iz ekonomije in vpišejo študij kitajščine ter kitajske kulture, končajo medicinsko fakulteto in vpišejo psihologijo, diplomirajo umetnostno zgodovino in vpišejo računalništvo. Ni nujno, da povsod diplomirajo, pomembno je, da dobijo znanja, potrebna za osebno kariero (Garrick, Rhodes, 1998).

$\mathrm{V}$ obdobju permanentega izobraževanja se izobraževanje nikoli ne konča. Človeku vedno na novo primanjkujejo določena znanja ali celo več znanj in sposobnosti hkrati. Česa se bo najprej lotil? Čemu bo dal pri izobraževanju prednost, je stvar jasnega izobraževalnega programiranja (Lewis, 1994). V življenjskem izobraževalnem načrtu dodaja posameznik nove oblike izobraževanja glede na to, kakšno šolsko, formalno izobrazbo ima, kaj se je imel priložnost naučiti po neformalni poti in kaj najbolj njegova prejšnja znanja in njegove sposobnosti ter lastnosti dopolnjuje (Billet, 1998).

Množično izobraževanje (en izobraževalni program za vse) ne ustreza več zahtevam postmoderne informacijske družbe. Množično izobraževanje po enem programu ne razvija človekove osebnosti in njegovih posebnosti, ni podlaga za ustvarjalnost in ne spodbuja samoiniciativnosti, samostojnosti, 
Vsebina posameznega izobraževanja ne more biti osamjen pojav. Povezuje ga osebni izobraževalni načrt in posameznikova življenjska kariera, prek katere se posamezna znanja povezujejo v strukturo, osmišljajo in dobivajo svojo jasno funkeijo. Brez jasno izdelanega osebnega izobraževalnega načrta postanejo stranpoti v učenju še pogostejš̌e in izobraževanje se upočasni (Dohmen, 1998).

sposobnosti odločanja in nekaterih drugih, za današnji čas bistvenih osebnostnih lastnosti. Različne kombinacije med rednim šolanjem in zlasti programi izobraževanja odraslih dajejo možnosti za posebno, neponovljivo kombinacijo osebnih znanj in s tem večjo posameznikovo konkurenčnost glede na njegove kompetence. Programiranje izobraževanja je v družbi znanja del preživetvene strategije.

\section{LITERATURA IN VIRI}

Anon: Nacionalni program izobraževanja odraslih, I. del, 1998, ACS, Ljubljana.

Anon: Nacionalni program izobraževanja odraslih, II. del, 1999, ACS, Ljubljana.

Bartlett, W., 1999: Adult Guidance Services in the European Learning Society, Studies in the Education of Adults, let. 31, št. 1, str. 21-34 Bielefeld, W. Bertelsmann.

Billet, S., 1998: Ontogeny and Participation in Communities of Practice: A Socio-cognitive View of Adult Development, Studies in the Education of Adults, let. 30, št. 1, Leicester, str. 21-34.

Brečko, D., 1999: Vseživljenjski razvoj osebnosti I. in II. del, Andragoška spoznanja, Ljubljana, let. 5, št. 2 in 3, str. 6-17 in str. $27-41$.

Dohmen, G., 1998: The Future of Continuing Education in Europe, Federal Ministry of Education and Research, Bonn.

Drofenik, O., 1997: Nacionalni program izobraževanja odraslih, Andragoška spoznanja, Ljubljana, let. 3, št. 3-4, str. 67-73.

Edwards, R., 1996: Postmodernism and Education, Routledge, London.

Findeisen, D., 1997: Kaj napravi manj izobražene odrasle drugačne, Andragoška spoznanja, Ljubljana, let. 3, št. 1, str. 27-30.
Findeisen, D., 1997: Programska prenova izobraževalnega sistema v Franciji, Andragoška spoznanja, Ljubljana, let. 3 , št. 3-4, str. 18-23.

Hall, B., 1998: The Nature of Transformation: Environmental, Adult and Popular Education, OISE, Toronto.

Jelenc, Z., (ur.), 1998: Vseživljenjsko izobraževanje in vseživljenjsko učenje, ACS, Ljubljana.

Krajnc, Ana, 1994: Funkcionalna pismenost, Andragoški center Slovenije, Ljubljana.

Kroflič, R., 1997: Kurikulum, Andragoška spoznanja, Ljubljana, let. 3, št. 1, str. 3-13.

Lewis, C., 1994: A Wish to Be, Element, Brisbane, Queensland.

Matzen, J. (ur.), 1997: Perspectiven der Erwachsenenbildung, Ev. Heimvolkshochschule, Bad Bederkesa.

Merrill, B., 1997: Working in Teams: implications for method in cross-cultural contexts, International Journal of University Adult Education, let. 35, št. 3, str. 1-9.

Neumann, R., 1997: Der Sprung über die Kompetenzbarriere.

Nuissl, E., 1998: Lernende Gessellschaft Europa, DIE, Hamburg, let. 5, št. 3, str. 23-26.

Peters, O., 1998: Bildungsbereich Weiterbildung, Juventa Verlag, Weinheim.

Rees, T., Rhodes, C., 1998: Deconstructive Organizational Learning: The Possibilites for a Postmodern Epistemology of Practice, Studies in the Education of Adults, let. 30, št. 2, Leicester, str. 172-184.

Sakaiya, T., 1992: The Knowledge - Value Revolution, Kodansha International, Tokio.

Schmidt, Vlado, 1982: Socialistična pedagogika - med etatizmom in samoupravljanjem, DDU Univerzum, Ljubljana.

Schuller, T., 1999: Investigating the Learning Society.

Strokovna izhodišča za nacionalni program visokega šolstva, 1997, Ministrstvo za šolstvo in šport, Ljubljana.

Studies in the Education of Adults, let. 31, št. 1, str. $1-10$.

Taylor, M., Tough, Alen, 1972: Adult s Learning Projects, OISE, Toronto.

Tremblay, P., 1997: The Explanatory of Good Practice Principles in Workplace Education, International Journal of University Adult Education, let. 35, št. 3, str. $38-47$.

Vidmar, Tadej, 1995: Ideja permanentnega izobraževanja pri J. A. Komenskem v delu Pampaedia, Andragoška spoznanja, let. 1, št. 1-2, str. 48-55.

Vogel, N., 1998: Organisation und Entwicklung in der Weiterbildung, Klinghart, Bad Heilbrunn.

Ziegler, C., 1997: Lernziel Demokratie, Böhlau, Köln. 